\title{
De novis libris iudicia
}

Fowler, R. (ed.), The Cambridge Companion to Homer. Cambridge, Cambridge University Press, 2004. xvi, 419 p. Pr. $£ 18.99$ (pb) / $£ 45$ (hb).

There is currently no shortage of Homeric handbooks: after (Brill's) New Companion to Homer (B), dating already a bit longer back (1997), we now have The Cambridge Companion to Homer (C), the subject of this review, and Blackwell's Companion to Ancient Epic (Bl), both published in 2004. These three volumesinevitably-for a great part deal with the same subjects (the Homeric question: $\mathrm{B}+\mathrm{C}$; the formula: $\mathrm{B}+\mathrm{C}$; structure of the Iliad and Odyssey: $\mathrm{B}+\mathrm{C}+\mathrm{Bl}$; historical background: $\mathrm{B}+\mathrm{C}+\mathrm{Bl}$; gods: $\mathrm{C}+\mathrm{Bl}$; epic as genre: $\mathrm{B}+\mathrm{C}+\mathrm{Bl}$; women: $\mathrm{C}+\mathrm{Bl}$ ), in chapters which are occasionally even by the same authors (Lamberton writes about Homer in antiquity in both B and Bl; Raaflaub about Homeric society in both $\mathrm{B}$ and $\mathrm{Bl}$; Edmunds on myth in both $\mathrm{B}$ and $\mathrm{Bl}$ ). The one big difference of $\mathrm{C}$ in comparison to both $\mathrm{B}$ and $\mathrm{Bl}$ is its section on ancient and modern reception, which ranges from chapters on Homer and Greek literature, via Homer and the romantics, to contemporary receptions of Homer. This is a laudable initiative, which, however, has not been entirely successfully executed. The choice of subjects is simply too random.

The aim of The Cambridge Companion to Homer is "to provide essential advice for the novice and to suggest further directions for research" (7). In other words, the chapters aim at sketching the state of the art. Most of them have, I think, succeeded in this goal, although there is one general point of criticism which I want to raise. It is clear that the contributors have been instructed by their editor (who in turn will have been instructed by his publisher) to concentrate on English scholarship, in view of the expected predominantly English readership of this Companion. In a way this makes sense and is defensible, and yet at times I was a bit annoyed by the repeated invisibility or absence of German scholarship. I mention two particularly clear examples: the chapter on "Epic as Genre", which has much on the Serbo-Croatian parallel, does not mention the work of G. Danek, who has published extensively on this subject. ${ }^{1)}$ The chapter dealing

1) In WS 104 (1991); 109 (1996); 111 (1998). 
with "The Epic Tradition in Greece", which pays considerable attention to neoanalysis, does not mention W. Kullmann, who has devoted a lifetime to neoanalytic work on Homer and whose ideas are also available in English, ${ }^{2)}$ nor G. Danek, who has published a fist-sized neo-analytic commentary on the Odyssey. ${ }^{3)}$ A laudable exception here is Scodel, who in her section of further reading even recommends a study by Rothe from 1910, which (she herself notes) is still in Gothic script. The innocent novice might come away from reading this Companion with the idea that Homer has been or is studied mainly by English scholars. The inability to read German, which apparently—still-characterizes the average English and American student, should not lead to such a gross distortion, and even though German works most probably will remain unread, they deserve to be mentioned when the state of the art of a particular subject is described.

If this companion is intended primarily for the novice, I would hesitate to advise that novice lecture of the first chapter by Lateiner on the Iliad. It proceeds by very broad generalizations and wild ideas, and hardly gives a balanced view on the very different readings this poem has yielded. As so many Americans today, the author seems influenced by the Vietnam-war and paints a very negative picture of Achilles as a berserker hero, who looses all human decency after loosing his best friend. In its details, too, this chapter simply abounds in claims and generalizations which are either wrong or deserving a much more subtle discussion: "Iliadic warfare beyond the duel is hard to visualise" and "highly unrealistic" (p. 13) - Lateiner has missed here the work by Latacz and Van Wees, ${ }^{4}$ who have done much to show the system in the madness of Homeric warfare; "the big chief Agamemnon seizes the indispensable lesser chief Akhilleus' dearest prize" (p. 15) - the truth of the matter is, however, that Akhilleus is no lesser chief (see Taplin and Van Wees); ${ }^{5)}$ I would be loath to teach my students that the embassy in Iliad 9 is a ruse (p. 15) or that "the poem's finale portrays all parties as

2) See, e.g. 1960. Die Quellen der Ilias (Wiesbaden) and 1984. Oral Poetry, Theory and Neoanalysis in Homeric Research, GRBS 25, 307-23.

3) Danek, G. 1998. Epos und Zitat (Wien).

4) Latacz, J. 1977. Kampfparänese, Kampfdarstellung und Kampfwirklichkeit in der Ilias, bei Kallinos und Tyrtaios (München); Van Wees, H. 1994. The Homeric Ways of War, I: The Iliad and the Hoplite Phalanx, G\&R 41, 1-18.

5) Taplin, O. 1990. Agamemnon's Role in the Iliad, in: Pelling, C. (ed.) Characterization and Individuality in Greek Literature (Oxford), 60-82. Van Wees, H. 1992. Status Warriors. War, Violence, and Society in Homer and History (Amsterdam). 
exhausted" (p. 21). Finally, I noted narratological anomalies, such as "the omniscient Ionian narrator" (13), and "Thersites focalising the point of view of the men in the bivouacs" (p. 20).

The chapter by Silk on the Odyssey is much better, though I was surprised to see him adhere to the old idea that Books 5-12 are a flashback, i.e. that the divine council of Book 5 signals a return in time to the divine council in Book 1. Athena's speech in the council of Book 5 is simply full of references to events from Books 1-4, and therefore makes very clear that we have moved forward in time.

The chapter by Scodel on "The Story-teller and His Audience" might create false expectations: it does not deal with the narrator and his narratees, but mainly with the selection by the poet of his material and the prior knowledge of his addressees. It is thus in fact rather a chapter on neo-analysis (she does mention Danek!).

In her chapter on the gods Kearns has chosen for a fruitful and innovative combination of a discussion of the role of the gods inside and outside the epics. The chapter by Clarke on "Manhood and Heroism" is in my view one of the best of the volume. It offers a subtle discussion of what it means to be a mortal and a hero in the Homeric epics and concerning our appreciation of that most complex hero of all, Achilles, provides a much better introduction than Lateiner's.

The chapter on gender by Felson and Slatkin presents a reasonable if to my taste somewhat sloppy discussion of this topic. I simply came across too many statements which do not describe a point aptly or precisely to be fully happy with the overall picture. Let me give an example. On p. 109 we read: "the fact that he (Odysseus) narrates these escapades [with Circe and Calypso] to Penelope (as earlier to the Phaeacians) indicates that they do not constitute a violation of societal norms and in his poem they threaten neither patriarchy nor patriliny"; but the truth of the matter is that Odysseus, addressing his wife, actually skips the erotic part of his stays with Circe and Calpso (cf. 23.321 and 333-7)!

Clark's chapter on formulas, metre and type-scene is an excellent introduction to this technical subject. Griffin effectively embarks on a discussion of the Homeric speeches via Plato's experiment of getting rid of the speeches: this is the same as taking away the heart of the epics. Focusing on the speeches of Iliad 1 he manages to give a good idea of the variety in tone and their characterizing function. Buxton's chapter on the similes in general offers a lucid introduction to their main functions and the dazzling variety of vehicles they employ. The only aspect which remains somewhat underdeveloped is the structural function of similes, their capacity to connect different parts of the narrative. An example is the pair of shipwreck similes found in Odyssey 5 and 23, which link the fates of Odysseus and Penelope, who both have to suffer dangers and hardships before 
reaching the safety of the 'shore' again. This example in my view may also serve to modify Buxton's claim that in the Odyssey similes "do not carve out for themselves a truly central role in the constitution of the epic's meaning” (p. 149).

The chapter by Foley on "Epic as a Genre" consists of two parts, a comparatistic section on other epics, which brings home very clearly the important point that epic is in fact a multifarious genre, and a second section in which what is epic in Homer is inventorized. Of these two sections, I found the first illuminating (though I was surprised that no Eastern parallels were included), the second rather disappointing. Thus the brief discussion on formulas on p. 182 is superficial and outdated, and had better been replaced by a cross-reference to Clark's chapter.

Dowden's chapter on “The Epic Tradition in Greece” contains an interesting introduction mainly to the Epic cycle, recently so much in the picture (apart from Burgess, mentioned by Dowden, there is Anderson, ${ }^{6}$ not mentioned, and the Loeb edition by Martin West). The summaries on pp. 198-200 are most helpful.

Osborne's chapter on Homer's society consists of three parts: 1) the societies in which the epic was shaped; 2) the societies created in the poems; and 3) their relationship. Of these, I found (1) and (2) clear and helpful summaries of what is now generally thought about these notoriously complex matters, but (3) is a bit too hasty. Rather than discussing the various positions which are taken up nowadays: a) the world depicted in the epics is an ahistorical amalgam; b) the world depicted is by and large the world of the poet, with some references to earlier ages; and c) the world depicted is essentially the Mycenaean world, with occasional references to the poet's own times, Osborne quickly opts for (b), without discussing (c) at all. ${ }^{7}$

The chapter by Fowler on "The Homeric Question" in my view is one of the best of the volume. I particularly appreciated his clear and detailed discussion of that vexed question of the transition from oral to written. The model he comes up with (p. 230) is worth quoting in full here: "Perhaps one could describe the progression thus: 1) non-fixed, because oral; 2) oral, with many consciously fixed passages; 3) mostly fixed, and therefore written; 4) written to start with, and therefore fixed. In Homer's day, I suggest, Greek epic moved through (2) to (3)."

I conclude that this volume cannot be said to fill an urgently felt scholarly desideratum, that the report on secondary literature is often misleading in its

\footnotetext{
6) Anderson, M.J. 1997. The Fall of Troy in Early Greek Poetry and Art (Oxford).

7) A defender of this last position is Latacz, J. 2004. Troy and Homer. Towards a Solution of an Old Mystery (Oxford) (translation from the German edition of 2001).
} 
English-slantedness, but that there are also many excellent chapters, which deserve to be warmly recommended to students.

Universiteit van Amsterdam

Irene J.F. de Jong

Klassiek Seminarium

Spuistraat 134, 1012 VB Amsterdam

The Netherlands

i.j.f.dejong@uva.nl 
Radt, S. (Hrsg.), Strabons Geographika, 3: Buch IX-XIII: Text und Übersetzung. Göttingen, Vandenhoeck \& Ruprecht, 2004. 681 S. Pr. € 192.

Radt, S. (Hrsg.), Strabons Geographika, 4: Buch XIV-XVII: Text und Übersetzung. Göttingen, Vandenhoeck \& Ruprecht, 2005. 574 S. Pr. € 169.

La publication des tomes 3 (livres IX-XIII) et 4 (livres XIV-XVII) des Strabons Geographika achève l'édition critique du texte et la traduction de l'ensemble des dix-sept livres de l'œuvre de Strabon préparée par S. Radt. On dispose enfin d'une édition complète, moderne et rigoureuse de la Géographie accompagnée d'une traduction allemande exacte et efficace. On peut dès maintenant affirmer que l'édition de R. s'impose comme un instrument de travail impeccable et comme un monument de la recherche philologique moderne, et pas seulement dans le domaine des études sur Strabon.

Il y aura encore assurément des passages dont le texte pourra être amélioré ou retouché en particulier à partir de la relecture du palimpseste Vatican (Vaticanus gr. $2306+2061 \mathrm{~A}+$ Crypt. Z.a.43) en utilisant les moyens récents de la science et de la technique, mais dans l'ensemble, cette édition restera le point de départ le plus fiable et le plus cohérent.

Les critères suivis par R. dans la présentation du texte et dans la rédaction de l'apparat de ces volumes ne changent pas par rapport à ceux des deux premiers (je les ai brièvement décrits dans mon compte rendu paru dans Mnemosyne 58 (2005), 140). La lecture des deux tomes est facilitée par les en-têtes au texte grec (livre, chapitre et page de l'édition de Casaubon, répétés aussi dans les marges) et à la traduction (indication sommaire du contenu des passages de la Géographie). Les lemmes de l'apparat reproduisent le texte édité, auquel on se réfère, ligne par ligne, suivant la pagination de Casaubon. L'apparat critique est accompagné d'une liste de Testimonia (omettant les extraits des mss. E X, qui seront publiés dans le tome IX). Un astérisque $\left(^{*}\right)$ précède les passages dans lesquels Strabon n'est pas cité par son nom, mais par une circonlocution.

La richesse de données qu'on retrouve dans l'apparat n'est pas un obstacle à sa consultation et le lecteur s'y repère sans difficulté. J'ai beaucoup apprécié la décision de l'éditeur de ne pas se limiter à signaler le seul nom des chercheurs ayant proposé une conjecture ou une correction (à l'exception bien évidemment des éditeurs de la Géographie), mais d'y ajouter aussi le titre de l'œuvre (souvent abrégé) ou de la revue où ils ont publié leurs propositions, en les accompagnant de l'indication de la page. Cela se révèle très utile surtout dans le cas de livres anciens ou rares ou de conjectures 'cachées' dans des contributions qui ne portent pas essentiellement sur Strabon. Dans le cas où la collation d'un manuscrit 
recentior a confirmé une conjecture déjà proposée par un ou plusieurs savants, $\mathrm{R}$. a choisi d'indiquer aussi à côté du sigle de(s) manuscrit(s) le nom de ceux qui avaient repéré ope ingenii la bonne leçon.

Dans l'établissement du texte, R. opte avec compétence et en pleine connaissance de cause pour les variantes des manuscrits, ou les conjectures des savants modernes, y compris les siennes, qui lui semblent le mieux contribuer à la restitution du texte 'original' de la Géographie de Strabon. Les passages crucifiés ne manquent pas, dans un souci admirable de prudence et d'honnêteté intellectuelle. R. signale toutes les propositions qui lui semblent convenables sans alourdir l'apparat, en renvoyant aux pages du commentaire pour la discussion des cas les plus complexes ou nécessitant une discussion plus approfondie. C'est donc avec impatience qu'on attend la parution des quatre prochains volumes consacrés au commentaire.

A la fin des deux volumes (III, pp. 662-80; IV, pp. 554-71), on trouve une Appendix apparatus critici (pour laquelle on peut se rapporter aux Prolegomena au premier volume: C2, pp. xvii-xviii), ainsi qu'une série de Korrigenda aux tomes déjà publiés (III, p. 681; IV, pp. 572-4; voir aussi II, pp. 559-60).

La brièveté de ce compte rendu ne trouve d'autre explication que la qualité excellente de l'œuvre qui en fait l'objet.

UPR 76-CNRS

T. Dorandi

7, rue G. Moquet, BP 8

94801 Villejuif cedex, France

tiziano.dorandi@wanadoo.fr 
Casevitz, M., Babut, D., Plutarque, QEuvres morales, t. XV.1. Traité 70-Sur les contradictions stoïciennes. Traité 71-Synopsis du traité "Que les Stö̈ciens tiennent des propos plus paradoxaux que les poètes". Texte établi par M.C., traduit et commenté par D.B. Paris, Les Belles Lettres, 2004. 384 p. Pr. € 54.

La publication du premier tome du vol. XV des CEuvres morales de Plutarque pour la Collection Budé complète la réédition des écrits que le savant de Chéronée avait adressés contre les Stoïciens. Le deuxième tome: Traité 72-Sur les notions communes contre les Stoïciens, était sorti en 2002.

Le volume dont on rend compte contient le Traité 70-Sur les contradictions stö̈ciennes, et le Traité 71-Synopsis du traité "Que les Stö̈ciens tiennent des propos plus paradoxaux que les poètes". L'établissement du texte des trois opuscules a été confié à M. Casevitz (dorénavant: C.), tandis que D. Babut (dorénavant: B.) en a assuré l'introduction, la traduction française et l'apparat des notes.

Les études de B. sur Plutarque et le Stoïcisme, bien connues et appréciées (je ne signalerai que sa monographie Plutarque et le Stö̈cisme (Paris 1969)), en faisaient la personne la plus qualifiée pour accomplir avec succès la tâche de traduire et commenter ces textes complexes et problématiques. B. n'a pas déçu les attentes.

Chaque traité est précédé d'une brève notice; le texte grec est accompagné d'une traduction française en face, et suivi d'un imposante série de notes.

B. consacre la Notice à l'écrit Sur les contradictions stoïciennes (pp. 3-20) à la discussion des sources et de la chronologie de cet opuscule. En ce qui concerne les sources, B. renonce à l'hypothèse de von Arnim (source unique dépendant probablement de l'Académicien Clitomaque), ainsi qu'à celles de Pohlenz et Sandbach (Plutarque aurait combiné une source principale, dans laquelle les contradictions des Stoïciens étaient groupées par sujets, et une ou plusieurs sources secondaires, utilisées dans des sections qui ne montrent aucun ordre logique dans la succession des arguments). En reprenant certaines remarques de Cherniss sur la structure du traité, B. souligne que "le désordre qui a tant frappé les commentateurs dans la composition de cette œuvre n'est pas nécessairement, ni même vraisemblablement, dû à l'utilisation de sources différentes maladroitement combinées par l'auteur" (p. 11), et arrive à la conclusion, à mon avis, convaincante que le De Stoic. rep. est "une œuvre de conception originale, dont l'auteur, sans entreprendre une critique systématique de la philosophie stoïcienne, avait tenté d'en mettre au jour un certain nombre de contradictions" (p. 13) à partir des données qu'il avait rassemblées dans les cahiers de notes ( $ं \pi \circ \mu v \eta ́ \mu \alpha \tau \alpha)$ rédigés à son usage personnel tout au long de sa carrière d'écrivain et de philosophe (pp. 13-4). J'ai étudié cette pratique dans les deux premiers chapitres de mon livret Le stylet et la tablette (Paris 2000). 
La chronologie du traité n'est pas facile à déterminer, faute d'éléments concrets. B. suppose "avec un degré raisonnable de vraisemblance" (p. 16) qu'il a été composé à une date relativement ancienne. Il se peut que le De Stoic. rep. soit plus ancien que les Dialogues pythiques, ce qui nous fournirait un terminus ante quem, qu'il n'est pas possible de reculer jusqu'au début de la production littéraire de Plutarque "en raison de l'ampleur des connaissances et des lectures qu'implique sa conception” ( $\mathrm{p} .17$ ) et des références qui y sont faites à deux œuvres antérieures dirigées contre les Stoïciens. On peut donc proposer pour le De Stoic. rep. une date "qui ne semble pas pouvoir être de beaucoup antérieure aux années 80" (p. 18).

Dans les dernières pages de la Notice (pp. 20-2), C. présente une description assez sommaire (et en quelques cas imprécise) des principaux manuscrits: la date du ms. X y manque; le ms. F y est (correctement) daté de la fin du $\mathrm{X}^{\mathrm{e}}$ siècle, tandis que dans l'index siglorum sa date est postérieure d'un siècle ("s. XI ex."). Un index siglorum suit (pp. 23-4). Aux abréviations des éditeurs et des savants, il faut ajouter: Emp. $=$ Emperius, Salm. $=$ Salmasius, et Xyl. $=$ Xylander. Dans celui du Synopsis, p. 101, manque Wy. = Wyttenbach.

Un des objectifs visés dans le long commentaire (265 pages en petits caractères) qui accompagne la traduction est "d'être en mesure de porter un jugement plus équitable et plus équilibré qu’on ne l'avait fait jusqu'ici sur la valeur de ces écrits et sur le profit que peut en tirer notre connaissance de la philosophie postclassique, et plus spécialement notre compréhension de la pensée stoïcienne" (p. 18). B. cherche aussi à défendre Plutarque, dont la "bonne foi n'est jamais en défaut" (p. 19), contre ses détracteurs, et à démontrer que ce traité "reste, malgré ses défauts, un document dont aucun historien du stoïcisme ne peut méconnaître la valeur informative et l'intérêt intrinsèque" (p. 20).

La lecture des 620 notes est assurément instructive. On est impressionné par la profondeur de la doctrine et par l'étendue des connaissances de B. non seulement pour la philosophie stoïcienne, mais aussi pour l'ensemble de l'œuvre de Plutarque (il y a des notes qui occupent plusieurs pages: p. ex. les notes 263, 311, 548 ou 600). B. y exploite ses qualités de philologue attentif et soucieux de la langue et du style de Plutarque, et d'expert de questions philosophiques. Je voudrais attirer l'attention sur les nombreuses notes 'philologiques' (communes aussi au Synopsis), dans lesquelles B. explique et justifie avec force arguments certaines de ses propositions (p. ex., De Stoic. rep., n. 61, 112, 123, 127, 363, 481 et 605; Synopsis, n. 19) ou celles de ses prédécesseurs (p. ex., De Stoic. rep., n. 46, 71, 85, $122,135,153,155-6,298,460$ et 506), ou il défend, souvent avec raison, le texte des manuscrits (p. ex., De Stoic. rep., n. 126, 134, 154, 315, 334, 375, 395-6, 467, 472 et 545; Synopsis, n. 24). 
La seule chose que je trouve plutôt gênante (mais B. n'en est pas responsable), c'est que les sigles bibliographiques ne sont enregistrées que dans le vol. XV.2 (pp. 37-48). Le lecteur est donc obligé d'avoir sous les mains les deux tomes et de passer incessamment de l'un à l'autre.

Dans la Notice au bref Traité 71-Synopsis du traité "Que les Stoïciens tiennent des propos plusparadoxaux que les poètes”, (pp. 95-100), B. discute de son authenticité ("l'auteur [quel qu'il ait été] à qui nous devons l'opuscule qui nous est parvenu, s'est contenté, selon toute probabilité, de reproduire sans rien y changer les quelques extraits du traité perdu de Plutarque qui lui ont paru les plus appropriés à en donner une vue 'synoptique'”, pp. 97-8), et de sa chronologie ("il paraît difficilement imaginable que cette œuvre ait pu être conçue et rédigée après le dialogue Sur les notions communes", p. 99). En ce qui concerne les notes, je ne puis que ratifier ce que je viens de dire à propos de celles du De Stoic. rep.

La traduction des deux traités est apparemment impeccable; j'aurais plus de mal à en dire autant de l'établissement du texte. On a l'impression de se trouver face à une édition peu soignée et hâtivement réalisée. J'aurais surtout évité-dans une édition Budé-la présence massive de formules telles que codd., rell. et surtout plerique, qui se répètent, monotones et agaçantes, page après page.

UPR 76-CNRS

T. Dorandi

7, rue G. Moquet, BP 8

94801 Villejuif cedex, France tiziano.dorandi@wanadoo.fr 
Spevak, O., La concession en latin. Brussels, Éditions Latomus, 2005. 260 p. Pr. $€ 40.00$.

Concessive clauses are treated in every Latin grammar, but in most cases rather cursorily. This is a pity since they present a number of interesting problems. Spevak's work, a revised doctoral thesis, discusses these issues thoroughly and in a very accessible style. Every claim she makes is supported by Latin examples with translations. For these reasons, La concession en latin will be an important contribution to the study of subordinate clauses in Latin.

The book is divided into an introduction, a first part dealing with concessives in classical Latin, and a second part dealing with concessives in late Latin. The introduction treats various topics, for instance the use of the term concessio in ancient rhetoric, but the most important sections are undoubtedly those in which a typology of concessives is introduced. While this typology may not be entirely new, based as it is on work by Martin, ${ }^{1)}$ its application to Latin in the chapters to follow is original and a real achievement. Spevak distinguishes between various kinds of concessives. The simple type (even though it is raining, he is going out) consists of a reason (rain) and a consequence (going out) which is different from the expected consequence (staying at home). Conditional concessives (even if ) contain a non-asserted hypothesis instead of a reason, and this hypothesis is the most extreme of all possible cases. Scalar concessives (bowever good it is) are similar in that they also present the most extreme degree possible. Spevak discusses some other subtypes as well, including cases in which the concessive meaning is not made explicit syntactically. What I also found very interesting is the section in which Spevak, following König, ${ }^{2)}$ discusses the origin of concessive words (p. 19); they typically go back to words or phrases signalling universal quantification (all the same), free-choice quantification (however good), conditions (normally with a focus particle, even if), coexistence without hindrance (nevertheless), or scorn (despite).

The first part after the introduction is in effect one long chapter (pp. 29-130) and treats concessives in classical Latin. After looking at some terminological problems, Spevak draws a distinction between concessive words proper, such as quamquam, and those which do not have concessive meaning in themselves, but whose clauses can often be interpreted as concessive because of conversational

1) Cf. Martin, R. 1982. Relation concessive et univers de croyance, Modèles linguistiques 4, 27-39, and 1987. Langage et croyance: Les univers de croyance dans la théorie sémantique (Brussels).

2) Cf. for example König, E. 1985. On the History of Concessive Connectives in English: Diachronic and Synchronic Evidence, Lingua 66, 1-19. 
implicatures, for example cum and dum. She then examines in detail how the different types of concessives are normally expressed in classical Latin; scalar concessives, for instance, require an intensifying word such as quamuis, while a word like etsi is excluded (p. 47). Spevak does of course take the etymologies of the various concessive subordinators into account, but she also makes it clear that the synchronic meanings cannot always be accounted for by them. Thus, tametsi, which contains the conditional si, is nevertheless mainly employed in factual contexts (p. 99) and tends to introduce simple concessives (p. 107).

The second part, which discusses concessives in late Latin, is divided into five chapters. Spevak uses two corpora for her study, both of which contain prose and poetry from the fourth and early fifth centuries. Her main corpus includes works by Symmachus, Ammianus Marcellinus, Augustine, Jerome, Prudentius, Ausonius, Claudianus, and Sidonius. Her secondary corpus contains Sulpicius Severus, Ambrose, the Historia Augusta, Egeria, and Vegetius.

The first chapter of this second part deals with finite concessive clauses. Interestingly, concessive clauses more often than not precede their main clauses. Clauses introduced by licet, quamuis, and quamquam precede in $56 \%$ of the cases, and those introduced by etsi precede in $82 \%$ of the cases (p. 146). Spevak notes that etiamsi differs from etsi in that it merely precedes in $49 \%$ of the tokens, but since there are only 44 tokens in total, I wonder if this is statistically significant. The majority of postposed concessives are afterthoughts (p. 149), or 'restrictive', to use Spevak's term, which means that there is no alternative order. Spevak also tells us that tamen picks up a preceding concessive clause in three quarters of the tokens in prose, while in poetry tamen is used more rarely in this function (p. 147); for etiamsi the use without tamen predominates, but again the figures are low. Spevak's treatment of the moods is instructive. Licet and quamuis almost always take the subjunctive, and this is the predominant mood for quamquam as well, but some authors also take the indicative after quamquam, which Spevak regards as deliberate imitation of classical authors. Ammianus' use of the moods after these three subordinators depends on other factors like rhythm or modal attraction. After $e t s i$ and etiamsi both indicative and subjunctive occur in all authors, the distinction being one between factual and non-factual.

In the next chapter, Spevak turns to non-finite concessives. Ablative absolutes, participles, and several other types of constituents can receive a concessive interpretation. Sometimes the concessive meaning is made explicit by the use of words such as licet. The following two chapters are not about a contrast between finite and non-finite concessives, but between what Spevak calls "concession argumentative" and "concession textuelle". The former concerns the type si tibi est machaera, at nobis ueruinast domi (Pl. Bac. 887). We are dealing with concessives on the illocutionary level, that is, the concessive gives a reason which should 
prevent the speaker from uttering the main clause, but he or she does so nevertheless. Textual concession marks a concessive relationship between two independent clauses, of the type arbitrer baiulum festinasse? Quamuis longae epistulae una nox sufficit (Hier. epist. 7.2).

After this, Spevak summarizes the uses of the concessive words in a separate chapter and then, in the final chapter, draws her general conclusions. At the end of the book, following the bibliography, there is an index rerum, a very useful index locorum, and a table of contents which is so detailed that it almost makes the index rerum redundant. In conclusion, Spevak's book is a sound and very readable contribution to the study of concessive constructions and will be warmly welcomed by anyone interested in subordination in Latin, especially late Latin. The book contains few misprints or other mistakes. ${ }^{3)}$

All Souls College

Wolfgang David Cirilo de Melo

University of Oxford

High Street

Oxford OX1 4AL, UK

wolfgang.demelo@all-souls.ox.ac.uk

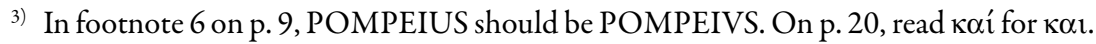
At the bottom of p. 21, "autoriseraient" should be "autoriserait". On p. 31, quamuis ought to be divided quam-uis, not qua-muis (also on pp. 36, 80, 156, 158 note 12, 193, and 227-8). In footnote 6 on p. 34, read "Martín Puente" for "Martin Puente". In footnote 28 on p. 55, Spevak uses Risselada's term 'disinterested permission', but spells it "des-". In footnote 30 on p. 56, "car elle souvent utilisée" should be "car elle est souvent utilisée". On p. 66 I cannot agree with all the etymologies; synchronically it is of course true that quam and tam have $a$-vocalism, while cum, tum, dum, and num have $u$-vocalism, but the second group is not homogeneous: cum, tum, and dum originally had $o$-vocalism, and only num has inherited its - $u$-. Similarly, not all the parallels for $-a$ - from other IndoEuropean languages in footnote 44 are relevant; thus, in the Baltic forms, $-a$ - can of course be inherited, but it could also come from ${ }^{*}-o$-, and in Vedic, $-a$ - can come from ${ }^{*}-a-,{ }^{*}-o-$, or ${ }^{*}-e-$. On p. 67 Spevak argues that the doubling found in quamquam or quisquis was only productive before the historic period, but she also claims that $u b i u b i$ is not lexicalized; this seems contradictory to me. In example 16 on p. 72, uobis cum should be uobiscum (similarly, replace te cum (p. 101, example 21) by tecum). In example 45 on p. 81 we should read Menti rather than menti. Example 10 on p. 84 is shortened, like some of the other examples in the book; however, the change from crinem to crines is unwarranted. Another point to note about the examples is that Spevak takes practically all translations from the Budé editions. Sometimes the Latin text and the translation do not match exactly. On some occasions, the translation contains more material than the shortened Latin quote, for instance in example 20 on p. 139, in example 12 on p. 153, in 
example 18 on p. 157 , or in example 30 on p. 163 . In example 17 on p. 224 it is actually the Latin text which is longer; moreover, the comma after recipi makes the sentence somewhat difficult to understand. Yet there is only one example whose presentation I found genuinely confusing. In example 16 on p. 138, the Latin text reads Natus licet ille sororue uel coniunx fuerit... se licet illa... iactet sentiet iratam procul aegida, sentiet. The two mistakes (iratam for iratum and aegida for aegide) in combination with the omissions make the sentence hard to understand; the original has Natus licet ille sororue uel coniunx fuerit natarumue agminis una, se licet illa meo conceptum uertice iactet, sentiet iratum procul aegide, sentiet ictum fulminis. Unfortunately, the translation does not entirely match the Latin text either in this example so that the reader does not get much help from it. Let us return to the other slips. The first paragraph on p. 85 should end with a full stop rather than a comma. In footnote 65 on p. 85, Spevak cites Cic. Mur. 8: neque... licet neque integrum est, ut laborem non impertiam. According to her, this is the only example of $u t$ following licet in classical Latin. However, it seems to me that $u t$ instead of the plain subjunctive is only used because of integrum est, which is why I would not consider this a true exception. On pp. 79-80, Spevak comments on sint quamuis boni that this can be interpreted in two ways: if quamuis modifies boni alone, the meaning is 'however good they may be', but if quamuis is a "particule concessive", the meaning is 'even though they are good'. This second reading seems practically impossible to me because the verb precedes quamuis; extraposition of verbs is extremely rare. In footnote 59 on p. 82, there should be a comma before "KüHNER-STEGMANN" and one after the page number following "SZANTYR". On p. 88, there should be no full stop after "employé absolument". In footnote 79 on p. 92 I was not convinced by the etymology of oportet. The traditional derivation from ${ }^{*}$ op-wortēt may have its weaknesses, but it seems even less likely to me that the Czech form treba should go back to an Indo-European root ${ }^{*}$ terband that this root should somehow be part of Latin oportet. In example 11 on p. 98, "son l'amitié" should be "son amitié". In example 16 on p. 100, res bene est gesta must be replaced by res bene gesta est, otherwise the line does not scan. On p. 107, Tametsi should be italicized entirely. In example 44 on p. 110 and underneath, "absoluement" should be replaced by "absolument". On p. 111, "Letoublon" should be "Létoublon". On p. 144, "méta-comunicative" ought to be "méta-communicative". On pp. 147-8, the figures for conditionals are neglected in the data. On p. 153, Etna should be Aetna. On p. 156 it is claimed that example 14 contains non amiserint, which is incorrect; I am not sure if Spevak had a different passage in mind because a search of the BTL-CD (version 3 ) gives no hits for amiserint in combination with non and licet. In footnote 10 on p. 157 there should be no comma after Fid. Likewise, there should be no comma after Prof. in example 22 on p. 160. In example 31 on p. 164, we should have pleraeque licet instead of pleraeque, licet. Example 1 on p. 178 should have been translated as a question. On p. 180, "Le subordonnant cum" should be "Le subordonnant cum". Example 14 on p. 181 is difficult to follow because the function of $e t$ is unclear; if Spevak had quoted a bit more, it would be obvious that another $e t$ is following ('both ... and'). In footnote 35 on p. 187, hic must be replaced by huic. On p. 193 there should be a full stop before Licet. In exam-

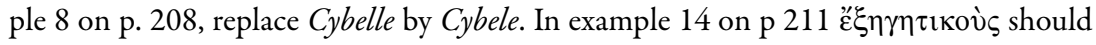


not have an acute accent over the first vowel. In footnote 9. on p. 216, read donent for donnent.

The bibliography (pp. 237-46) and indices (247-53) are useful and accurate. However, in Bennett's book "Syntaxe" should be "Syntax". Bertocchi's 1998 article was published in a book edited by García-Hernández, not Garcia-Hernández. In Blumenthal's article, "Function" should be replaced by "Funktion". Ferrarino's article appears in a journal that has "Accademia" rather than "Akademia" in its title. König's 1986 article is in a book called "On Conditionals" rather than "On Conditionnals". In Kroon's book, "et" ought to be replaced by "and". Lease's article contains the word "Konstruktion", not "Konstruction", and the journal contains the word "Lexikographie" rather than "Lexicographie" (Spevak misspells this journal title after Hartel's article in the same way). The book in which Longrée's article appeared contains the word "Akten", not "Acten". In Martín Puente's book, "concesividad" should not have a double -ss-, and in the thesis that was turned into this book we should read "oraciones", not "orationes". In Núñez's book, "Semantica" and "latin" should be replaced by "Semántica" and "latín", respectively. In Pfister's article, read "Randschärfe" instead of "Randschaerfe". Pinkster's 1983 volume contains "Linguistic Theory" rather than "Linguistics Theory". In Schaffner's book, "lateinisches" ought to be "lateinischen". In the index locorum, Horace's epodes precede the epistles, but otherwise it is alphabetical. 
May, J.M. (ed.), Brill's Companion to Cicero: Oratory and Rhetoric. Brill, Leiden/ Boston/Köln, 2002. xiii, 632 p.

"The authors of the essays in this volume offer their works as a companion to the study of Cicero's oratory and rhetoric, for both students and experts in the field. We hope that it will become a vademecum of sorts: for the neophyte, a starting point; for the veteran, a place for renewing the dialogue... about issues concerning Ciceronian oratory and rhetoric..." (p. ix). This work, in the series of Brill's Companions, as a whole comprises seventeen chapters, which are presented roughly in chronological order, followed by a consolidated chronology (by C.P. Craig, pp. 533-99), a general index and an index locorum (pp. 601-32).

May (Chapter 1: "Cicero his Life and Career", pp. 1-21) provides a general background essay very suitable perhaps for the "neophyte", but possibly to be bypassed by fellow specialists. A chronology and a bibliography conclude this section, the latter being the common and rather repetitive feature of all sections. Corbeill (Chapter 2: "Political Education in Cicero's Youth", pp. 23-48) focuses on the de Divinatione and the ad Herennium, which "examine this period (the 90s) and the ensuing decade to show how tensions between Greek influence and Roman heritage are reflected in what is known of Roman pedagogical practice" (pp. 24-5). This is basically a comparative study of the contents of these two works to show that Cicero's is the earlier, and is probably aimed more for a scholarly readership. In Chapter 3 May ("Cicero's Oratory in Context", pp. 49-70) attempts to "set the context within which an orator like Cicero operated, in the hopes of providing a kind of orientation for those who are new to, or not entirely familiar with, the kinds of rhetorical situations that Cicero faced as a public speaker, and the strategies that he commonly employed in them" (p. 51). M. also notes that even among a possible relatively high literacy rate and where the use of inscriptions, art and coins were used to disseminate information, "Roman society remained extremely dependent on the spoken word" (p. 53), and makes the interesting point, certainly for those not acquainted with the period, that any oral presentation was consumed by an aurally acute and therefore highly sophisticated audience (p. 54).

The chronological order is resumed by Vasaly (Chapter 4: "Cicero's Early Speeches", pp. 71-111), who argues for example that the publication of the Verrines was a monument "of the enormous effort that had gone into the prosecution of Verres... of Cicero's rhetorical ability... as a source of public renown and self promotion as memorable as the games, building projects, and festivals he would oversee in his aedilician year" (pp. 91-2), although no record of these remains. There are points here, which the neophyte should be aware of. 
For instance, V. presumably confuses the "aged law expert" (pp. 71-2) Q. Mucius Scaevola, who had been consul only in 95 and was killed aged about fifty-eight, with the cos. 117 (cf. Wisse p. 379); de Republica appears in two different spellings twice (pp. 80-1, p. 108) without explanation; the "talented young Sulpicius" (p. 85) was roughly thirty when he first appeared in a legal case and was hence older than Cicero, yet the period up to his debut is described as having been "unusually long" (p. 72). The comparative chronology requires some attention and with it the appropriate descriptions. Cicero obtained the right to proceed as prosecutor against Verres ousting the claim of Q. Caecilius Niger; however, this politician was not related to other Caecilii mentioned on the same page (p. 88) and, again, an unfamiliar reader could be easily misled, while "Massilia (Marseilles)" (p. 90) is surely unnecessary. Verres' debauchery while proconsul in Syracuse (p. 100) as the text clearly reveals occurred on the parkland on the southern tip of Ortygia near the present Castello Maniace, where no "beach" has ever existed. The senators of the Roman republic were never a "hereditary... class" (p. 102) and Scipio Aemilianus (p. 103) conquered Carthage and Numantia, but not Sicily (p. 103), and neither did Africanus the actual subject of Verr. 2.4.80-1. Inconsistencies may be noted in the footnotes in this section, but also elsewhere (cf. pp. $401 \mathrm{ff}$.), while throughout the volume common abbreviations could have easily been employed.

Cape (Chapter 5: "Cicero's Consular Speeches", pp. 113-58) examines "Cicero's consular corpus as a conscious selection of material designed to illustrate his consular ethos through examples of practical political negotiation" (p. 115). This discussion takes as it departure point Att. 2.1.3, but, although interesting, depends on the orator having had a plan beforehand, which may only be surmised. Chronological ambiguity is again apparent here (p. 141) as is a certain laxity in expression (pp. 130, 146, 152). Riggesby (Chapter 6: "The Post Reditum Speeches”, pp. 159-95) tackles Cicero's outpouring, often vitriolic, delivered on his return to Rome in 57 from exile. Since these speeches addressed a wide range of topics (p. 160) R. focuses on common themes: history, counter-history, the hidden present, praise and blame, consensus, religion, crime and politics. "Cicero's recall... is one of the key events in Cicero's Roman history" (p. 167), and his speeches were intended to enhance that event with mostly denigration of opponents such as Piso, Gabinius and, of course, Publius Clodius. The footnotes in this chapter are rather erratic (pp. 168-9, cf. elsewhere pp. 213, 215), and errors in the text may also be noted (pp. 175, 182, 186; again cf. 221, 251, 516). Corbeill (Chapter 7: "Ciceronian Invective", pp. 197-217) concentrates on the "recognizable categories of invective", "Cicero's deployment of these" and "how Roman sources identify invective" (p. 199), Gotoff (Chapter 8: "Cicero's Caesarian Orations", pp. 219-71) on the contents of the three speeches delivered by 
Cicero before Caesar: pro rege Deiotaro, pro Ligario, pro Marcello, and "from the personality Cicero creates for his speaker how he thought his audience (in other words, Caesar) might best be won over" (p. 224).

In tabulated form, Hall (Chapter 9: "The Philippics", pp. 273-304) gives the background of each of the Philippics (p. 274) followed by a useful brief synopsis of each, highlighting the most important "rhetorical features", particularly the use of the "rhetoric of crisis... wit and ridicule... praise and honorific decrees". For $H$. these speeches represent the apex of Cicero's oratorical career showing "no sign of stagnation or decay" and that "the quality that stands out most of all... is their vigor" (p. 302). Crawford in focussing on the lost and fragmentary orations (Chapter 10: pp. 305-30) presents, again in tabulated format (p. 327), the interesting fact that Cicero published less than half of his known speeches and of those seventy-nine circulated, nearly a quarter remain only as fragments or as references in other works. Wisse (Chapters 11 and 12, pp. 331400) initially discusses Roman attitudes to Greek culture and learning (p. 333) picking up from Corbeil's discussion in Chapter 2-then (p. 354) "standard rhetorical theories" which are "relevant for understanding Cicero's works", and afterwards turns to a more detailed analysis of the de Oratore in which Cicero arrives at "his idiosyncratic and surprising picture of the ideal orator: the Roman statesman who combines eloquence with universal knowledge" (p. 397). Narducci discusses the Brutus (Chapter 13, pp. 401-25) and the Orator (Chapter 14, pp. 427-43) and what constituted for Cicero the ideal orator-himself!

In Chapter 15, Gaines (pp. 445-80) takes a look at Cicero's Partitiones Oratoriae and Topica, usually "characterized as minor works", composed between 55 and 44, nonetheless, in G's opinion with "serious theoretical intentions". Kennedy (Chapter 16, pp. 481-501) winds up the proceedings with a survey of the reception of Cicero's rhetorical works from later antiquity, the Renaissance finally to Trollope, who developed "a special love for Cicero" (p. 498). C.P. Craig (Chapter 17, pp. 503-31) concludes with a "survey of selected recent work on Cicero's Rhetorica and Speeches," over the last thirty years or so.

This is a lengthy and replete volume, but with, perhaps understandably, variable content, sometimes very useful for the newcomer, sometimes useful for a more specialised readership. The Companion will obviously be used as a work of reference for further studies of Ciceronian oratory and rhetoric, possibly rather more often than as a "vademecum" - its sheer size, and for the neophyte its cost, will surely have put paid to that. 
Rosenstein, N., Rome at War. Farms, Families and Death in the Middle Republic. Chapel Hill/London, University of North Carolina Press, 2004. x, 339 p.

This is a brave and admirable book for a number of reasons. It is the first monograph in the field of Roman history that explores demography as a result and cause of specific historic developments. It relates mortality and fertility to Roman wars fought from the fourth to the second century $\mathrm{BC}$ and offers demographic developments as the root cause of the Gracchan crisis. While not all of its arguments are totally new, the book manages to present a new model for the background to Tiberius Gracchus' measures of land reform. Demographic developments played a role in the discussion before, but Rome at War brings the discussion onto a new and higher level. In the traditional view, the peasantry declined as a result of the devastations of the Hannibalic War, or because of the heavy burden of military conscription, or as a result of the expansion of large plantation-type latifundia, or a combination of these factors. Nathan Rosenstein, professor of history at Ohio State University, goes one step further and offers a truly demographic explanation, arguing that the conditions that governed births, marriages and deaths among the peasantry were such that the rural population increased quite steeply in the second century BC, leading to poverty and land hunger. Hence, Tiberius Gracchus did not address a problem of manpower shortage threatening Rome's military power, but the problem of poverty among potential recruits.

An introductory chapter gives an overview of the consensus arrived at in recent research on the development of agriculture in the late republic: slavery was nothing new in the second century BC, but latifundia can really only be detected on a larger scale from the late second century BC onwards. The next chapters deal with a few persistent misconceptions about the relationship between military service and the peasantry. First, Rosenstein tackles the conventional view that the nature of Roman wars in the second century BC was more detrimental to the peasantry than that of previous wars. He shows that already in the late fourth and third centuries BC, troops were kept in the field (or the camp) throughout the year. He also shows that the duration of service was not qualitatively different. Hence the long-term withdrawal of labour from the farms at the time of year when it was needed was no new development.

More importantly, he draws attention to the fact that small-scale farming in Roman Italy was likely to be characterised by underemployment of available labour. In order to make his point, Rosenstein calculates the labour requirement and capacity of a number of model families, each varying somewhat in their composition. Starting with the calorific requirements of a particular family, he calculates the amount of wheat which this represents, the area of land required 
to grow it, and, finally, the necessary labour to work this amount of land. The conclusion is that most families with adult sons had a high calorific requirement, but also the labour to produce it. This calculation requires his families to have access to more than twenty, even thirty iugera of land. Since Rosenstein agrees that most Roman peasants did not actually own so much land, he assumes that they had ready access to sufficiently large plots of ager publicus. It is questionable that at all times (indeed, at any time) Roman citizens could have exploited as much ager publicus as they needed. After all, when Tiberius Gracchus wanted land to be distributed to the peasantry, he was forced to take it from the wealthy farmers occupying it. Moreover, Flaminius' popularity in the years preceding the Hannibalic War was based on his distribution of land in the ager Gallicus. Rosenstein himself makes the point that this shows a high demand for land.

Rosenstein's models of farming may be criticized for being somewhat rigid, since the balance of their means of production-land, labour and capital-determined the way that peasants cultivated their land. For most smallholders, shortage of land was the crucial factor, forcing them to intensify their farming practices. This fundamental difference between arable farming on peasant farms and on commercial villas seriously diminishes the usefulness of Columella's figures on the amount of work needed for a iugerum of grain land. Intensifying the use of labour also meant making full use of external employment. Hence, at some stages of their family cycle, the labour requirement of some of Rosenstein's model-families may have been significantly higher than he calculates, but at the same time they may have been relying less on ager publicus than he assumes. Despite this criticism of his methodology, I agree with his basic conclusion that underemployment among the peasantry limited the negative impact of the withdrawal of labour by conscription. ${ }^{1)}$

Regarding the impact of conscription on farming and households, Rosenstein makes an important and crucial observation. He points out that the Romans mobilised young adults. Few men of over thirty will have served in the legions. As far as we know-the sources are limited to a much later as well as predominantly urban and well-to-do context-Roman men tended not to marry before their thirtieth birthday. Hence the vast majority of Roman legionaries were unmarried. On the other hand, veterans returning home with their savings and donatives were eager to marry young women, including the sisters of those serving in the legions. In this way, Rosenstein makes the important point that the men in the Roman armies did not have farms and families that relied on their

\footnotetext{
1) Erdkamp, P. 1998. Hunger and the Sword. Warfare and Food Supply in Roman Republican Wars (264-30 BC) (Amsterdam).
} 
labour or protection. In short, it is sound to conclude that under normal circumstances the mobilisation of soldiers had no adverse impact on the survival of households. The Hannibalic War is a different matter. While normally some thirty percent of all young men had at some point to serve in the armies, during the Hannibalic War up to seventy percent of young men were at some point mobilised. This exceptional situation, Rosenstein notes, may have been detrimental for those families that had little labour available to begin with.

One may add that complex households also alleviated the impact of mobilisation. In peasant societies, household structures were determined by the circumstances that governed the functioning of these households. Limited availability of land was one factor that stimulated economic co-operation or co-residence of siblings. During the Republic the high degree of mobilisation required by Rome's never-ending wars may have constituted another impetus for the formation of complex households, which made it easier to balance available labour and land. Moreover, recruitment into the legions or employment in the army or fleet as muleteer, rower and the like offered a means of subsistence for young men and thus a means to reduce pressure on the limited resources of peasant households at the time. ${ }^{2)}$ This is not to say that recruits always welcomed being drafted into the army, but often they-and their families-did.

The next step in Rosenstein's argument is to hypothesise an extremely high rate of mortality among conscripts. He calculates that between 4.75 and 5.45 percent of recruits died annually. In other words, assuming twelve years of service, 32-40 percent of recruits did not return. While a high rate of mortality among recruits is likely, this chapter is the least rewarding of the book. Rosenstein begins by assessing the number of Roman casualties in battles on the basis of the figures provided by Livy. Most of these figures derive from Valerius Antias, who is condemned even by Livy for his untrustworthy figures and for making up battles that never occurred. ${ }^{3)}$ Even if we agree that some of these figures derive somehow from official data, it is difficult to assess their meaning. How reliable are the generals' figures? Did generals count the dead? Did they count those soldiers missing after the battle was over, including deserters? Did they include the wounded and those dying days after the battle? The figures presented by Livy are difficult to begin with, and they are certainly not capable of supporting the elaborate construction of figures that Rosenstein builds up. Casualties of small-scale fights, for instance, are simply calculated as one half of those dying in battle. As Rosenstein points out, in early-modern armies more soldiers died from

2) See n. 1 .

3) Ziolkowski, A. 1990. Credibility of Nnumbers of Battle Captives in Livy, Books $X X I-X L V$, La parola del passato 45, 15-36. 
diseases than from fighting, but we lack any quantitative evidence. The numbers presented by Rosenstein may be in the right order, but two decimal points cannot hide the fact that his estimate of mortality among conscripts is not more than an educated guess.

It may also be pointed out that Rosenstein applies these mortality rates to model life tables in order to asses the impact on Roman age structure and population size. However, apart from the many reservations regarding model life tables, argued very well by Walter Scheidel, ${ }^{4)}$ there is one main problem: model life tables are constructions of the age structure, i.e. the number of people born and dying at each particular age, of stable populations. In other words, they assume no growth and no migration. Rosenstein, however, who assumes continuous population growth among Roman citizens from the fourth century onwards, nevertheless uses life tables that assume population stability.

Really innovative is Rosenstein's step to make the high mortality of conscripts the determining factor in the Roman republic's demographic regime. First, he hypothesises that the large number of farmers' sons never returning home increased the prosperity of those staying behind, as the latter had access to more (public) land. Since rural demand for land diminished, Rosenstein argues, the colonisation program was ended in approx. 180 BC. Peasants concentrated on the best arable land, thus improving land productivity. High mortality also increased the value of labour. Second, the birth rate was increased as the families wanted to ensure the survival of an heir, and as girls (and their parents) wanted to make sure that they could find a husband by marrying even younger. In this way, cultural norms about the age of marriage and the number of children were relaxed. This demographic tendency was even increased when in the second century BC many rural dwellers migrated to the city of Rome.

Rosenstein assumes three phases in demographic growth: in the fourth and third centuries a high rate of war-related mortality went hand in hand with a high fertility regime resulting from a low age of marriage for women and a high degree of female nuptiality. These high rates of births and marriages were maintained throughout the Hannibalic War. Due to this war and the increased wareffort of the first decades of the second century BC (in the East, Spain and northern Italy), fertility and population growth increased even more. However, at some point population growth caused increased pressure on the land and poverty, the problems that Tiberius Gracchus wanted to address.

Rosenstein has managed to develop a model that takes into consideration the complexity of demography and draws a coherent picture of causes and events. His hypotheses are carefully argued and he explores in detail many issues that are

4) Scheidel, W. 2001. Roman Age Structure, JRS 91, 1-26. 
relevant to his main theme. Does that mean that now all has been said that can be said about the demographic development of the Roman Republic? It is hardly diminishing the value of the book when this question is answered in the negative.

Rosenstein carefully shows how one factor led to another, for instance how mortality relates to fertility, and how prosperity relates to nuptiality, drawing on modern parallels to circumvent the dearth of source material on ancient demography. However, his model may be concentrating too much on one possible set of variables and on one particular way they might interact. In other words, Rosenstein carefully construes a development from high mortality among conscripts to high fertility, to population growth, and to poverty. Other developments may have taken place that worked in another direction, and one may arrive at the same end result (numerous, but poor rural masses) by using a different model.

In order to support his argument that mortality caused a rise in prosperity of the survivors, Rosenstein refers to the impact of the plague on early-modern European demographic and economic development. In this case, population decline caused the prosperity of the masses to rise (at least in Western Europe). Marginal lands were abandoned, causing a rise in agricultural productivity, while the value of labour increased. Prosperity caused higher nuptiality in the west, lower ages of marriage and thus higher fertility, although at first this was offset by high mortality levels. Is this model plausible for the republican situation? Problematic is the fact that, unlike Western Europe, nuptiality is supposed to be high and female age of marriage low to begin with. Moreover there is a fundamental difference between the European experience of the late Middle Ages and the Roman republic, since epidemics caused high mortality among both men and women, while Rosenstein postulates high mortality only among young men.

Increased mortality among conscripts does not necessarily (or even probably) lead to higher nuptiality, younger ages of marriage of women and higher fertility (a crucial point in Rosenstein's model). Because women are the ones who bear children, and men are only indirectly relevant to fertility, the issue is what happened to girls and women. One would suppose that in a society where the mortality rate of adults was high, there would be many more women aged fifteen to twenty-five than there were men aged thirty to forty. A high rate of mortality among conscripts would only increase the difference. Rosenstein's argument that parents wanted to ensure that their daughters found a husband by marrying them off young is unfounded and implausible. Whom did the women marry? One option would have been to lower the age of marriage of those young men not serving in the armies. After all, only a minority of young men served in the legions, and, as Rosenstein points out, economic conditions could relax cultural norms about marriage. Moreover, all of this is argued in a total absence of data, 
since we have no evidence whatsoever on the age of marriage of the rural masses in antiquity (outside Egypt).

A question not addressed by Rosenstein is the rate of re-marriage among widows. Again, in a pre-industrial society where women married much older men, we should expect many widows. Widows marrying less or not at all would reduce fertility. Why not assume that nuptiality among women declined instead of rose? Rosenstein agrees that a relative lack of men would mean increased competition. Daughters needed dowries to attract good husbands. Increased mortality among conscripts even increased the value of dowries. Rosenstein argues that households wanted to have an heir and therefore stimulated fertility. However, heirs were preferably sons, not daughters or their offspring. It is not unlikely that, as the number of men of marrying ages declined, female infanticide or exposure (in particular in households already having daughters) or better treatment of boys would diminish the chances of survival of girls. Fewer girls reaching reproductive ages would lower fertility.

Can we explain population growth among the rural masses without the alleged growth-stimulating impact of mortality among conscripts? I think we can, as the following sketch may show. Growth in the fourth and third centuries may be related to expansion, as a result of which land was distributed regularly. At the end of the third century, the Hannibalic War caused a brief but steep decline. Not only men died on the battle field, but also women, children and the elderly as a result of starvation and epidemics that were the result of war-time disruption and temporary migration. Even more important than the census figures are the proxy data corroborating population decline: after the Hannibalic War colonists were difficult to find; much land was available to colonists; migration shows that people expected to find a living elsewhere; several thousand Ligurians were settled in Samnium. In short, a situation emerged similar to late medieval Europe, when marginal lands were abandoned, productivity rose, and prosperity increased for the survivors. Epidemics in the 180s killed many people of all ages, thereby slowing down recovery. High rates of mortality among adult males may also have slowed down recovery (for various reasons, including the ones mentioned above). Nevertheless, the population recovered and grew beyond pre-war levels. Migration towards Rome and conscription in the armies served as a means to withdraw (temporarily or permanently) excess labour. At some stage, however, possibly in mid-century, growth caused land hunger, while at the same time less land became available. No colonies were founded, no land annexed in Italy. Demographic factors that are partly determined by cultural factors, such as nuptiality and age of marriage, will respond to changed conditions only after a considerable time-lag. Expectations based on past experiences play a large role here. In the mid-second century the expectation that land would 
become available or that migration to Rome or other cities would be an option for those without sufficient access to land would slow down the balancing out of material resources and fertility. Hence, even after land was becoming scarce, women kept marrying young and in large numbers, having many children and probably living in complex households. In short, we arrive at the same conclusion as Rosenstein, but along a different path. ${ }^{5)}$

This criticism is not meant to diminish the importance of Rosenstein's book, since it opens up a new and promising line of enquiry and will undoubtedly stimulate much debate. Hence, it will serve more than most monographs appearing in ancient history to improve our understanding of the ancient world.

Universiteit Leiden, Geschiedenis

Postbus 9515

2300 RA Leiden, The Netherlands

p.erdkamp@let.leidenuniv.nl

Paul Erdkamp

5) For a full-scale reconstruction of the demographic development of third- and secondcentury Italy, see de Ligt, L. 2005. Poverty and Demography. The Case of the Gracchan Land Reforms, Mnemosyne 57, 725-57. 
Malitz, J., Nero (translated from the German by A. Brown). Malden, MA/ Oxford/Victoria, Blackwell Publishing, 2005. 174 p., 9 b/w figs.

This short biography is a literal translation of the 1999 book published by C.H. Beck at Munich. The text presents a good, albeit not flashy, biography of one of the 'bad emperors' of the Roman empire. Rather than discussing Nero's life in a rigidly chronological order, Malitz singles out several aspects of Nero's life and deeds, in order to reconstruct a trustworthy image of that short but very vexed period from 37 to 68, especially the reign between 54 and 68. There are neither notes nor bibliographical references for each chapter, but the author provides a succinct bibliography of two pages at the end of the book. This shows that there was no updating of the text after the German edition. It is strange to see that no publications from other language areas than German and English are listed and that, for instance, the conference series Neroniana has not been consulted. The biographies by Eugen Cizek (1982), Marisa Ranieri Panetta (1999; admittedly, rather journalistic), Richard Holland (2000) and Edward Champlin (2003) are lacking in the list.

Malitz does not often discuss various pros and cons of interpretations and refrains from polemical opinions. In line with this Blackwell series of short biographies, he follows the general opinion as this has come into being over the last decades. Nero, however, has not become the cliché monster as he is usually portrayed. His interest mainly concentrated on the arts and even in his last days he was troubled by the condition of his voice instead of that of his reign. After his death, the young emperor remained quite popular in the East, what can be explained according to Malitz because of his genuine interest for the Greek, eastern parts of his Empire; his predecessors had always concen-trated on the western provinces. Nero's Nachleben in this book is limited to Sienkiewicz' 1896 novel Quo vadis? and one of the nine movies made after that work.

As an appendix a translation of parts of Suetonius' Nero is included. I do not understand why the old version by J.E. Reed from 1889 has been chosen: it is entirely outdated. Are there concerns for copyrights? As such, the idea of adding the main source is a good idea, especially as the book is meant in the first place for non-specialist readers. But then I should have added Tacitus and Dio Cassius as well. Citations from these sources in the text are also mainly taken from old translations. Postbus 9103, 6500 HD Nijmegen

The Netherlands

e.moormann@let.ru.nl 
Cotton, H.M., Rogers, G.M. (eds.), Rome, the Greek World, and the East, vol. 2: Government, Society and Culture in the Roman Empire. Chapel Hill/London, The University of North Carolina Press, 2004. xvii, 470 p. $£ 43.95$ (cloth) / $£ 20.50$ (paperback).

Without doubt, Fergus Millar is one of the most influential ancient historians of the twentieth century. Modern scholars of the Graeco-Roman world will know many of his essays and books, but the initiative to bring together in three volumes his most important articles published since 1961 gives these particular articles a better accessibility and appropriate prominence that they deserve, both for research and for teaching purposes. Volume two contains Millar's work on the empire as a system of government in the first three centuries $\mathrm{AD}$, and several studies on cultural and social phenomena, with a special focus on the eastern half of the Roman Empire. In order to create the best possible intellectual coherence, as stated in the introduction, the essays themselves appear broadly chronological by subject matter, and not necessarily chronologically by publication date (p. viii). The editors, H.M. Cotton and G.M. Rogers, have succeeded in presenting an excellent and well-chosen collection of twenty essays that not only gives a good sense of developments and innovations in the work of Millar himself, but also within the broader field of Roman history over the past four decades.

The volume is divided into two parts. Part one deals with many of the practical aspects of the functioning of government in the Roman Empire, with a particular focus on the role and influence of the emperor. What did emperors do? How did emperors communicate with their subjects? The image of being accessible to his subjects was of great importance to an individual emperor (ch. 1). The correspondence of Pliny with the emperor Trajan gives an excellent and full account of the (re)actions of emperors to particular issues and situations and also of the way emperors communicated with their officials who had been sent out to the provinces as representatives of the imperial government. In reaction to problems that were brought to his attention, an emperor needed as much information as possible in order to deal with a situation accordingly. How did he get his information? These practical issues of internal and external communication and the basic physical realities of travel in the imperial period play an important role in the second chapter. In one way or the other, all essays in this first part are connected with the larger themes of Millar's monumental work The Emperor in the Roman World (31 BC-AD 337), in which he established the 'essential passivity' as our leading model for the functioning of the Roman Emperor.

The essays on the fiscus (according to Millar best translated as the imperial estate') and on the aerarium show the significance of these financial institutions as important components for the functioning of the imperial government (chs. 3 
and 4). Millar regards the fiscus, apart from being a financial institution, as a clear symbol of the victory of the imperial institutions over the old republican ones (p. 72). Especially, in chapter five on cash distributions and imperial minting, one of Millar's great strengths becomes visible, for in this essay he demonstrates that he is a master in asking the right questions, even though-as he often points out himself-in many cases it will not be possible to answer them. The significance of posing these questions should not be underestimated, because it forces scholars to look in different directions for unusual angles. In this fifth chapter it becomes painfully clear how little we know of many aspects, especially the practical ones, of the functioning of Roman government. As Millar asks, how did cash distributions and imperial minting function from a practical point of view? How were mines exploited, and how was the material transported from the mines? What about transportation of tax money? This last question has caught the attention of several modern scholars over the last few decades (for instance, Hopkins, Duncan-Jones, and De Ligt). Millar wonders, and rightfully so, why there is so little trace of such important matters in our ancient sources (p. 95)?

No empire can function in isolation, but is always confronted with peoples and relations that are at and beyond its frontiers. Millar has given much attention to this important topic throughout the years. In the three essays that are included in this collection, he deals with questions on imperial policy and foreign relations, on emperors and their dealings with embassies from foreign peoples and client kingdoms, and on the tension that could potentially arise for subjects of client kings who also had to obey and live under the rule of a Roman emperor (chs. 9, 10, and 11).

In the second part of the volume, the essays contain a variety of issues in the cultural and social sphere. Repeatedly and from different perspectives Millar poses the question of how it must have been like to be part of the Roman Empire, both at the individual and community level. The twelfth essay on local cultures and the use of local languages, Libyan and Punic, in Roman Africa demonstrates how limited our knowledge is of these cultures and languages. Without a proper understanding of these it will never be possible to get a full sense of life in the provinces.

Chapter fifteen, "The World of the Golden Ass", i.e. the world in Apuleius' Metamorphoses, has become a classic masterpiece and model for historians who attempt to abstract 'historical reality' from 'fiction'. Compare this essay also with chapter 6 in the volume on the philosopher Epictetus and the use of his philosophical treatise as an historical source for social and political life in the Empire.

Two essays in this collection are reviews by Millar of works by other eminent ancient historians, Georg Pflaum and Sir Ronald Syme (chs. 8 and 18). For both these reviews one should also read the "Author's Prologue" in volume one, because there Millar comments on some of the issues he brought up in these 
two essays as well. Of particular interest in these reviews is that Millar presents some of his own views on modern scholarship in the field of ancient history. For example, Pflaum's admirable prosopographical work has led to a much better understanding of the equestrian career. Although indispensable as the basis of many studies in ancient history, as Millar's essays on P. Herennius Dexippus and M.Cn. Licinius Rufinus both demonstrate (chs. 13 and 20), prosopography has its limitations, for instance in that it excludes large groups of Roman society which are of crucial importance if one wants to write a social, economic or cultural history of the Empire. Millar himself has clearly moved beyond the prosopographical approach, as seen in The Emperor in the Roman World (31 BC-AD 337), in which he focused much more on the emperor as an institution' of the Empire.

In most of his essays Millar presented innovative and ground-breaking work, often dealing with subjects that either had been neglected or had not even been 'discovered' as topics. For instance, the essay on hard labor (ch. 7) is clearly pioneer work, whereas in his essay on Italy (ch. 17) he attempts to put the Italian peninsula, which as he argues lacks a 'narrative history under the empire', back on the map. In the last two essays Millar brings Roman law and jurists to the fore as good examples of a subject that has been neglected in modern scholarship (chs. 19 and 20).

Apart from the structure of the book into two parts, several essays can also be grouped together under the headings of larger themes, such as administration (chs. 1 and 2), finances (chs. 3, 4, and 5), frontiers and foreign relations (chs. 9, 10, and 11), or Roman law (chs. 19 and 20). In particular for teaching purposes this grouping into themes is useful.

Even though Millar seems apologetic about not always knowing the answers to his questions, this should clearly not be taken as a lack of knowledge, for his astonishing understanding of and stunning familiarity with the ancient sources can only be admired. He also seems tireless in his efforts to ask novel and original questions of old material that lead to new developments within the field of ancient history. The fact that this volume deals with such diverse topics can only be ascribed to the amazing scope of Millar's interests and knowledge. This volume is a splendid illustration of how Fergus Millar has influenced the way in which ancient history today is being practised.

Radboud Universiteit Nijmegen

Daniëlle Slootjes

Afdeling Geschiedenis

Postbus 9103, 6500 HD Nijmegen

The Netherlands

d.slootjes@let.ru.nl 
Howgego, C., Heuchert, V., Burnett, A. (eds.), Coinage and Identity in the Roman Provinces. Oxford, OUP, 2005. xv, 228 p. Pr. $£ 80$.

The publication of the first volume of the Roman Provincial Coinage (RPC) series in 1992 has rightly been heralded as a momentous occasion in the study of Roman imperial history. Like Steinby's Lexicon Topographicum Urbis Romae and Talbert's Barrington Atlas, RPC has rapidly become not only seminal, but indispensable. It has allowed scholars to easily access the vast source material which is supplied by provincial coinage, and widened the scope of research enormously. It is, therefore, all the more surprising that as to yet relatively little attention has been given to the ways in which this 'new' material can be employed systematically. The volume under review, based on papers given at the 17 th Oxford Symposium on Coinage and Monetary History (19-22 September 2002) proposes to do just that, and "review the rich evidence of provincial coinage" (p.v). Editors and authors are eminently qualified for this task (Howgego and Heuchert are editing the $R P C$ volume on the Antonine period, whilst Burnett has originated the project as a whole), and the book succeeds admirably in its purpose.

The time span of the volume exceeds that of $R P C$, which starts in $44 \mathrm{BC}$. One contribution, by Ripollès, deals with Spain from the period of the Second Punic War onwards, whilst an article by Williams focuses specifically on pre-conquest Britain. Thus, Roman provincial coinage is placed in context-which becomes even clearer by looking at alternatives, such as the coinage minted during the Jewish revolts. The end of the period under discussion is straightforward. During the reign of Diocletian the last provincial coins were minted in Egypt. After that, 'provincial' mints struck only standardized imperial coinage, with the Genius of the Roman people as commonest iconography: a Latin symbol for the whole empire (p. 16).

The themes of the volume are set out in a stimulating and bibliographically rich introduction by Howgego ("Coinage and Identity in the Roman Provinces", pp. 1-17). In it, he illustrates the possible ways in which coins can help to explore (collective) identities by looking at seven different categories, with the explicit purpose to "open things up a bit" (p. 2). The categories are well-chosen and fairly straightforward: religion, uses of monumentality, representations of the past, uses of time, geography, language, and 'Romanness. Consistently, Howgego shows how provincial coins tend to give 'sideways views' to what have become common assumptions. One may have become used to the predominance of religious structures on provincial coins, yet it is worth remembering that depicting buildings on coins was an essentially Roman innovation. A more 'internal' identity could also be made explicit through coinage, either through foundation 
myths, or through more indirect ways of emphasising the past—or indeed by showing autonomy through eponymous dating. Howgego argues rightfully that the names of local magistrates on coins cannot be said to be either for dating the coins or for claiming responsibility over the minting. They can be both simultaneously. To an extent, the same applies to the use of language on coins, especially bilingual ones: "two languages were used to express a double identity with a different content" (p. 13). This is best illustrated through a wonderful trilingual coin from the reign of Gordian III (pl. 1.4, 41-2), giving the name of the emperor in Latin, but also mentioning Dido in Greek and Elishar in Phoenician. Though there are clear restrictions to the ways coins can be used to detect local identities (they are explicitly public and reflect elite interest, as Howgego recognises), the benefits of using these local testimonies are equally obvious.

The other chapters of the book expand on Howgego's observations in several directions. At first, three more general themes are explored by respectively Williamson, Heuchert, and Weiss. In his decidedly provocative "Aspects of Identity" (pp. 19-27), Williamson stresses the variety of local identities and the possibility of plural identities, suggesting ways in which they can be made visible. Arguments range from the Dayton Agreement and McDonalds to the Lycian Marcus Arruntius Claudianus. Posing more questions than it answers, the piece clearly 'opens things up a bit', and helps further problematise the already problematic term 'identity'. Heuchert, in a long contribution (pp. 29-56), does exactly what the title of his chapter promises, and more. He sketches "The Chronological Development of Roman Provincial Coin Iconography”. The first half (pp. 29-44) is a somewhat technical but very lucid account of types, function, distribution, and control over provincial coins, including some extremely useful maps of cities issuing coins in the Eastern parts of the empire (pp. 34-9). Interestingly, the size of coins tended to increase over the years, allowing more elaborated imagery. The second half of the article discusses the images on both obverses and reverses. More than anything else, the richness of especially the reverse material (organised thematically) is striking. Here, also, most variation and innovation was possible-becoming more common from the second century onwards. Locally relevant imagery, from foundation myths to famous citizens, dominates, and Heuchert sketches some of the possible ways in which these images were designed or 'imported' over time. Lastly, Weiss discusses notions of control over the coinage more explicitly ("The Cities and Their Money", pp. 57-68), returning to many themes which he has touched upon in earlier writing. He notes that there is no consistent reason for naming governors on coins, but that, on the other hand, there is evidence for minting being often the result of euergetism. By making an epigraphic excursus on (honorific) statue 
dedication, he notes how similar the procedures for this and coin issuing were, making them both a clear reflection of elite notions.

The rest of the book is organised somewhat more haphazardly, with geographic and thematic contributions alternating inconsistently, though there is a general 'clockwise' geographic direction from Britain, via the East, to Egypt. The volume closes with a short overview by Burnett on "The Roman West and the Roman East” (pp. 171-81). An alternative arrangement would have been to differentiate between the articles discussing identities 'beyond Rome', then those looking at one or two provinces, followed by the pieces discussing more specific themes. The first category could consist of Williams' "Coinage and Identity in Pre-conquest Britain: 50 BC-AD 50" (pp. 69-78) and Ripollès' "Coinage and Identity in the Roman Provinces: Spain” (pp. 79-93), both of which sketch the impact of Roman coinage by comparing it with earlier periods, and Goodman's "Coinage and Identity: the Jewish Evidence" (pp. 163-6), which puts emphasis on discussing the coins of the AD 66-70 revolt. The second section would then include Kremydi-Sicilianou, “'Belonging' to Rome, 'Remaining' Greek: Coinage and Identity in Roman Macedonia" (pp. 95-106); "Religious-Cultural Identity in Thrace and Moesia Inferior" by Peter (pp. 107-14), and the very summary article by Geissen, “The Nome-Coins of Roman Egypt” (pp. 167-70). Butcher's "Information, Legitimation, or Self-legitimation? Popular and Elite Designs on the Coin Types of Syria” (pp. 143-56) notionally discusses one region as well, but is in reality a rich methodological piece on "mediating meaning" (p. 153). Finally, Price and Klose analyse coinage of the (cities of the) East as a whole from a thematic point of view, by looking at respectively "Local Mythologies" (Price, pp. 115-24) and "Festival and Games" (Klose, pp. 125-33). Similarly, KushnirStein only briefly reviews one element ("City Eras") within Palestinian coinage (pp. 157-61).

The study by Weisser (pp. 135-42) on the individual city of Pergamum, "to contrast with the broader regional surveys" (p. 135), and the general overview by Burnett would have made nice complementary conclusions; on the one hand one notes the importance of looking at coins within their city context and then contrast the different cities (Weisser), and on the other hand, as Burnett shows, there is a whole range of different contrasts that can then be taken into consideration, although there does seem to be a fundamental difference between East and West (if only for the period in which there was local coinage). Still, it is worth exploring other disparities, such as North vs. South, centre vs. periphery, or to "avoid polarization altogether and... find different patterns in different regions" (p. 180).

The volume as a whole illustrates how helpful local coinage is to question notions of identity. These notions are not only of extreme importance in under- 
standing how a system as ethnically diverse as the Roman Empire managed to exist fairly unproblematically, but are also at the heart of much of modern scholarship. It is surely more than a coincidence that the contributors themselves represent a wide array of ethnic and cultural backgrounds-often strongly related to the region they discuss-and that contemporary comparisons are not eschewed (e.g. the Euro, p. 1, or the World Trade Organization, p. 23). As could be hoped for of an OUP publication, the illustrations are of the highest quality, with a very useful key to the plates (though the references to the images for the chapter by Klose are rather minimal). The volume also includes a geographic and general index. This is a beautifully edited book that should be read for information and-perhaps even more-for inspiration. It should make those who were up to now unaware of the importance of $R P C$ realise how rich a tool provincial coinage is, and challenge all to employ this rich source in new and different ways.

Radboud Universiteit Nijmegen

Olivier Hekster Afdeling Geschiedenis

Postbus 9103, 6500 HD Nijmegen

The Netherlands

o.hekster@let.ru.nl 